\title{
Forum: Refleksi Ajeg Bali Hari Ini
}

\author{
Gede Indra Pramana \\ Ilmu Politik, Paska Sarjana Fakultas Ilmu Sosial dan Ilmu Politik \\ Universitas Gadjah Mada, Bulaksumur Yogyakarta 55281, Indonesia \\ Lembaga Studi Urban, Surabaya, Indonesia
}

Email: indra.prama@gmail.com

\begin{abstract}
This paper traces the discourse on Ajeg Bali. As a formulation for the crisis in the post-boom Bali bombing in 2002, Ajeg Bali is considered as panacea that can solve all problems. By tracing the Ajeg Bali discourse and practices revealed in his name, found that amid the onslaught of the power of capital, mighty Ajeg Bali served as servant of power.
\end{abstract}

Keywords: Ajeg Bali, discourse, empty signifier

Bom yang meledak pada malam 11 Oktober 2002 di Jalan Legian, Kuta, Bali menyentak dalam denyut nadi pariwisata di Bali. Ledakan ini tidak hanya menyebabkan jatuhnya korban jiwa, lebih kurang 300 korban jiwa melayang, termasuk sang pelaku. Tak lama berselang, negara-negara tetangga menerapkan travel warning pada destinasi wisata internasional terbesar di Indonesia ini. Hal ini berakibat lumpuhnya sektor ekonomi yang secara mencolok ditopang oleh industri pariwisata. Tak berhenti sampai disitu, ledakan ini juga membawa diskursus fundamentalisme dan keamanan nasional, suatu hal yang selama ini asing bagi masyarakat yang selama ini dibuai oleh industri pariwisatanya. Semua menjadi awal dari babak baru dalam dinamika masyarakat Bali hari ini.

Wajah muram pariwisata Bali, akibat bom, membawa pengaruh yang tidak dapat dikatakan kecil dalam membentuk pemahaman kita melihat Bali hari ini. Secara global, serangan bom ini berlangsung tidak lama berselang sejak serangan 9/11 World Trade Center, Amerika Serikat yang mengubah wajah politik global. Di antaranya, kebijakan global war on terror menjadi jawaban pemerintahan George W. Bush dalam menghadapi ancaman terhadap wilayah yuridiksinya. ${ }^{6}$ Paska serangan Bom Bali, lumpuhnya sektor ekonomi menimbulkan permasalahan-permasalahan yang tidak sedikit. Rendahnya tingkat hunian hotel, sepinya kunjungan wisatawan, berakibatnya menurunnya jumlah pemasukan dan tingginya angka pemutusan hubungan kerja di sektor industri pariwisata serta sektor-sektor pendukungnya. Bali tak lagi menikmati manisnya industri pariwisata.

\footnotetext{
${ }^{6}$ Doktrin Pre-emptive Strike menjadi dasar dalam melakukan tindakan pencegahan ancaman keamanan, dimana potensipotensi ancaman kedaulatan Amerika Serikat dilumpuhkan sebelum ancaman tersebut menjadi nyata, apapun bentuk dan dimanapun lokasinya. Di Indonesia kebijakan ini dilakukan dengan membangun detasemen khusus antiteror 88. Lebih jauh, lihat Hizkia Yosias Simon Polimpung, Psikoanalisis Paradoks Kedaulatan Kontemporer-Kasus Kebijakan Global War On Terror Amerika Serikat Semasa Pemerintahan George W. Bush, Jr, Tesis Universitas Indonesia, tidak diterbitkan.
} 
Ditengah-tengah lesunya ekonomi pariwisata, Satria Naradha, putra pendiri Bali Post, Ketut Nadha, mengenalkan suatu gagasan, Ajeg Bali, dengan tawaran semangat baru. Hadir pada saat krisis, gagasan ini mendapatkan tanggapan yang besar dari masyarakat Bali yang dalam kondisi ditekan secara ekonomi. Dengan tidak menawarkan suatu norma yang definitif, secara longgar jargon Ajeg Bali digunakan sebagai suatu arahan dalam menegakkan kembali suatu nilai-nilai ke-bali-an. Pada setiap kesempatan, di ruang kantor pemerintahan, universitas, warung kopi, sebutan ini hadir.

Kesibukan media terbesar di Bali ini kemudian mengkampanyekan Ajeg Bali diberbagai kesempatan, yang mana diawali dengan penandatangan prasasti Ajeg Bali yang dilakukan di kantor pers Ketut Nadha. Roadshow dilakukan berkeliling ke wilayah kota dan kabupatenkabupaten dimana Ajeg Bali diresmikan oleh pemimpin daerah bersangkutan, bahkan dilakukan komitmen bersama guna meng-ajeg-kan Bali. Akhirnya Ajeg Bali masuk dalam ruang-ruang dalam rumah keluarga Bali melalui siaran stasiun BaliTV yang notabene juga merupakan milik Bali Post Group. Dari sini muncul pertanyaan, apa dan bagaimana Ajeg Bali itu? Bagaimana konsekuensikonsekunsi dari praktiknya?

\section{Ajeg Bali dalam Pusaran Makna}

Sejak dua-tiga tahun belakangan ini, di Bali dimunculkan sebuah ikon Ajeg Bali yang mempertegas lagi batas-batas penanda identitas antara apa yang disebut sebagai 'Bali' dan bukan
Bali. Ikon ini berdampak luar biasa dalam ruang kesadaran orang Bali. Secara harafiah, kata 'ajeg' bermakna kukuh, tidak goyah, tegak, dan lestari. Kalau disandingkan, kata 'ajeg' dan Bali berarti Bali yang kukuh atau Bali yang tidak goyah.

Menurut Nyoman Wijaya (2010), Ajeg Bali menjadi seperangkat gagasan dan strategi guna menghadapi tantangan global. Guna menghadapi persaingan di bidang ekonomi, kemunculan Ajeg Bali secara spesifik memunculkan sentimen etnosentris. Gagasan tentang kembali ke adat, dan 'Ajeg Bali' juga sebuah latihan intelektual yang menghasilkan jawaban sementara tehadap tantangan zaman. 'Ajeg Bali' mengarah pada tindakan mencintai diri sendiri yang cenderung mengajak pihak lain untuk mengikuti nilai-nilai dan normanorma keagamaan yang diwariskan oleh leluhur sendiri dengan cara memanipulasi memori sosial.

Dalam wawancara yang dilakukan dalam kurun waktu 2004, Pamella Allen dan Carmencita Palerma mencatat beragam respon terkait pertanyaan “Apa itu Ajeg Bali?”, diantaranya":

Kadek Suardana (seniman):

Ajeg Bali itu tren, bukan sebuah tujuan.

I Made Sidia (dalang):

Ajeg itu kan stabil juga... lestari... apapun yang kita miliki harus dari warisan leluhur; harus kita terus lanjutkan biar ajeg, biar tetap tahan itu.

Jango Paramatha (kartunis/jurnalis):

Arti ajeg itu adalah sesuatu yang tidak dinamis, statis... Kata-kata dipegang oleh dua media sangat besar sekali, itu pengaruhnya luar biasasekali. Semuanya pada tanya: Ajeg Bali, Ajeg Bali! Itu luar

\footnotetext{
${ }^{7}$ Pamela Allen \& Carmencita Palermo (2005): Ajeg Bali: Multiple Meanings, Diverse Agendas, Indonesia and the Malay World, 33:97, 239-25 http://dx.doi.org/10.1080/13639810500449115 diakses pada 15 November 2011 pukul 00.30
} 
biasa sekali. Sekarang yang kita inginkan sekarang... secara positif, secara pikir bagaimana memberikan roh, soul, terhadap kata ajeg itu biar berarti benar. Biar berarti bukan... stagnan...apa namanya..bukan mematikan dinamika budaya

Gus Martin (kartunis/jurnalis):

...suatu kesadaran untuk memagari

budaya Bali... melestarikan adat Bali

Mas Ruscitadewi (penulis/jurnalis):

...cuman sebuah simbol untuk keinginan...harapan bagiamana biar Bali itu seimbang...harmonis, ada keharmonisan di Bali

IB Agastya (intelektual Hindu):

Ajeg itu kesucian Bali...Dibangun dari awalnya, dasarnya kesucian itu berkaitan dengan sastra kuno, tata ruangnya, gunung, laut, lingkungan hidupnya itu.... Itu kunci Bali di masa lalu tapi juga di masa datang.

Wayan Sunarta (seniman/penulis):

Konsepnya sebenarnya dilontarkan oleh Bali Post...yang merasa kewajiban untuk menjaga Bali. Tapi sebenarnya konsep itu telah digunakan untuk kepentingan politis.

Ngurah Suryawan (antropolog):

Saya ingat itu terutamanya muncul dengan keprihatinan Bali untuk bangkit lagi kepariwisataan

Rama Surya (jurnalis):

Di tengah situasi Indonesia sekarang ada otonomi, ada segala macam. Ini mungkin ada bagian dari strategi...

\section{Adakaitandenganotonomidaerah?}

Saya rasa ya.

Hasil wawancara menunjukan bagaimana beragamnya makna yang dapat dilekatkan dalam Ajeg Bali. Konsep ini semata-mata menjadi penanda kosong, dimana makna apapun dapat dilekatkan padanya. Ruang kosong inilah yang menjadi ruang pertarungan politis guna mendefinisikan apa dan bagaimana konsep Ajeg Bali, untuk selanjutnya menjadi dasar dalam menentukan sikap kita. ${ }^{8} \mathrm{Di}$ sini, Ajeg Bali menjadi logika kategori yang menentukan apa yang salah/benar, atau baik/buruk. ${ }^{9}$

Dalam praktik kesehariannnya, nilai-nilai tradisi Hindu Bali didefinisikan ulang dengan mengungkapkan Om Swastyastu di berbagai kesempatan formal maupun informal, yang ironisnya, penerapan ini baru santer dilakukan belakangan sejak maraknya kampanye Ajeg Bali. Di satu sisi ini merupakan suatu fenomena yang patut diapresiasi. Akan tetapi di sisi lain, meningkatnya penggunaan atribut-atribut keagamaan justru menandai suatu kesadaran defensif dari umat minoritas di negara demokratis muslim terbesar di dunia ini.

Secara logis, kesadaran orang Bali meningkat di tengah-tengah tekanan yang datang dari luar. Dalam konteks kekinian, serangan teroris memantik suatu sentimen agama, meskipun, belakangan dilakukan berbagai pendekatan guna memberi suata gambaran bahwa serangan tersebut tidak merepresentasikan sikap umum umat yang diasosiasiakan dengan fanatik yang tragis tersebut.

Di Bali sendiri tantangan ini dijawab dengan melakukan sweeping terhadap pendatang. Pendatang

\footnotetext{
${ }^{8}$ Konsepsi ruang kosong ini meminjam dari Ernesto Laclau. Mengambil inspirasinya dari kajian-kajian filsafat postrukturalis, Laclau bersama Chantal Mouffe mengkaji sejarah pemikiran kiri menghantarkannya dari logika kontingensi yang selama ini menggerakan perdebatan pemikiran kiri hingga ini. Gagasan tentang diskursus menghantarkannya pada pemahaman tentang temporalitas dari logika pemaknaan. Lihat Ernesto Laclau dan Chantal Mouffe, Hegemony and Socialist Strategy:Toward A Radical Democratic Politic, London: Verso, 2001, edisi kedua, naskah asli terbit 1985. Lebih jauh, lihat Ernesto Laclau, New Reflection on The Revolution of Our Time, London:Verso, 1990.

${ }^{9}$ Pembacaan ini dilakukan melampaui logika oposisi biner yang selama ini menjadi landasan positif dalam memandang realitas. Bandingkan dengan Michel Foucault, Power/Knowledge, Wacana Kuasa/Pengetahuan, Yogyakarta: Bentang , 2002.
} 
menjadi suatu kategori baru, di luar orang lokal, pelancong/wisatawan baik nusantara maupun mancanegara. Pendatang dilekatkan dengan orangorang luar, yang datang ke Bali, dengan status tidak sebagai wisatawan. Mereka-meraka inilah yang menjadi sasaran dari kebijakan pemeriksaan, wajib memiliki kartu tanda penduduk sementara, karena dianggap berpotensi buruk bagi keadaan Bali.

Sampai disini Ajeg Bali menjadi seperangkat gagasan dan strategi yang secara ofensif diterapkan di wilayah Bali. Penerapannya dilakukan secara sistematis, diorganisasi oleh berbagai perangkat institusi, baik pemerintah resmi maupun yang mengatasnamakan adat tradisi. Ajeg Bali menjadi senjata pamungkas yang dianggap dapat mengatasi segala problematika yang ada.

Pengangkatan pejabat-pejabat eksekutif di lingkungan birokrasi, maupun wakil rakyat di legislasi dilakukan dengan bersumpah akan mengajeg-kan Bali. Masyarakat dihimbau agar berperan aktif dalam menegakan Ajeg Bali. Masyarakat menjawab himbauan ini dengan hadirnya suatu entitas pengamanan swadaya, Pecalang, yang bekerja di ruang lingkup desa pekramanan. Pecalangpecalang inilah yang menertibkan pendatang, dan menjadi satuan keamanan yang bertanggung jawab, tidak hanya dalam ruang lingkup penyelenggaraan upacara agama, melainkan merambah ke industri hiburan dan pariwisata (Suryawan, 2004).

\section{Paradoks Ajeg Bali}

Di tengah hingar bingar kehadiran Ajeg Bali pada berbagai ruang-ruang sosial dan media, sikap orang Bali terhadap derasnya investasi dan kapital yang masuk terlihat kontradiktif. Tidak sedikit tanahtanah pertanian di Bali yang beralih fungsi menjadi hunian, baik hotel atau villa yang dibangun demi pariwisata. Perubahan fungsi tanah ini bukannya tidak disadari, akan tetapi begitu pesatnya perkembangan objek pariwisata ini sehingga orang Bali tampak terengah-engah dalam menyikapi perubahan ini.

Pengambilalihan tanah oleh Negara seringkali mengorbankan masyarakat lokal, bahkan mengangkangi kebijakan adat desa setempat. Kompleks Pengembang Pecatu Graha di Ungasan, Jimbaran, mengambil sebagian besar bibir pantai yang ada disana. Saat ini, meskipun pengembangan masih terkesan berjalan lambat, ke depannya dapat dibayangkan wilayah tersebut menjadi sentra baru bagi wilayah Denpasar Selatan, dimana Kuta dan Nusa Dua yang menjadi trademark saat ini sudah terlalu padat dan jenuh dengan mobilitas kapital dan pelancong. Meskipun hingga kini Kuta masih menjadi primadona, dibuktikan dengan Bakrie Grup mengambil alih kepemilikan tanah di bibir pantai Kuta dengan harga yang tidak murah .

Wilayah Pura Sakenan yang ditimbun dengan kapur juga bukannya tidak berimplikasi secara nyata. Meskipun sebagian wilayahnya saat ini menjadi konservasi hutan bakau, ke depannya wilayah strategis yang menjadi jalur urat nadi lalu lintas menuju atau keluar Bandara Ngurah Rai ini sudah direncanakan untuk menjadi superkompleks yang menyediakan berbagai layanan pariwisata, seperti kawasan perhotelan, hiburan, dan mall. ${ }^{10}$

\footnotetext{
${ }^{10}$ Menurut desas desus yang beredar, kedua kompleks ini, Pecatu Graha dan Sanggaran di sekitar pelaba Pura Sakenan menjadi milik Keluarga Cendana, dibawah kendali Tommy
} 
Tanah pelaban Pura, yang dulunya menjadi milik bersama desa adat, tidak lagi berfungsi menjadi sandaran kehidupan warga desa.

$\begin{array}{ccr}\text { Pengalaman } & \text { terdahulu dengan } \\ \text { pengembangan demi pariwisata tampaknya }\end{array}$
membutakan mata segenap masyarakat Bali dengan janji keuntungan materi yang menunggunya. Wilayah pantai Sanur sudah sejak dulu sebagian menjadi akses eksklusif Hotel Bali Beach di Denpasar. Kompleks perhotelan Nusa Dua bahkan secara dominan mengambil wilayah pantai di Nusa Dua, kemudian membangun tembok tinggi guna membatasi akses kesana. Hingga saat ini, banyak wilayah-wilayah pelosok di pedalaman Bali diincar untuk dibangun menjadi villa, dan orang Bali dengan senang hati menjual tanahnya. Alih fungsi lahan yang hingga saat ini tidak terbendung berpotensi menghancurkan keseimbangan dan harmoni alam yang sejak dulu menjadi pengetahuan lokal orang Bali.

Disini tampak Ajeg Bali kehilangan maknanya. Wajah garang yang ditunjukkannya bagi para pendatang tidak berarti apa-apa, lemas berhadapan dengan gempuran modal yang datang dari investor atas nama pembangunan. Desa adat, dan aparatus keamananannya, Pecalang, tunduk dihadapan aliran dana dari investor yang menjanjikan materi bagi pendukungnya.

Paling akhir adalah polemik Rencana Tata Ruang Wilayah yang melibatkan Pemerintah Pusat, Gubernur Bali, Walikota Denpasar, Bupati Badung, Dewan Perwakilan Rakyat Daerah (DPRD) Tingkat I Provinsi Bali, DPRD tingkat II Kabupaten

Soeharto. Di wilayah Sanggaran bahkan santer terdengar akan didirikan kasino.
Badung, dan DPRD tingkat II Kota Denpasar, serta organisasi-organisasi masyarakat sipil. Guna meningkatkan kualitas industri pariwisata yang menggeliat paska Bom, dengan meningkatnya acaraacara tingkat internasional yang mana Bali menjadi tuan rumahnya, berencana membangun Bandara baru di wilayah utara Bali, sekitar Kabupaten Negara dan Singaraja. ${ }^{11}$ Kemudian, dilakukan juga pembangunan di jalan bypass Ngurah Rai yang menghubungkan antar bandara menuju destinasi lain di wilayah Bali. Sejauh yang penulis pantau, terdapat tiga skema yang akan dilakukan dalam membangun infrastruktur pendukung. Yang pertama adalah membangun jalan layang diatas jalur bypass Ngurah Rai, melintasi Simpang Siur Kuta, dan dibangun dua jalur yang menghubungkan Kuta menuju Denpasar. Yang kedua adalah membangun underpass di jalur yang sama. Opsi terakhir adalah dengan membangun jalan tol yang menembus wilayah pinggiran pantai mulai di depan airway Bandara Ngurah Rai yang terletak di bypass hingga ke wilayah Sanggaran di terminal kargo pelabuhan Benoa di wilayah Sanggaran, Sesetan, Denpasar. Terjadi pro-kontra yang hebat yang dimuat di harian Bali Post selama berminggu-minggu. Terlepas dari berbagai opini tentang pembangunan ini, lagi-lagi yang menjadi penonton adalah masyarakat Bali sendiri yang seolah-olah pasif.

\section{Tantangan Masa Depan Bali}

Berbagai problematika yang hadir silih berganti menuntut solusi dan jawaban. Jika tidak bergegas,

\footnotetext{
${ }^{11}$ Rencana ini disambut dengan gegap gempita, dimana terjadi pengalihan kepemilikan tanah secara signifikan di lokasi Bandara ini akan dibangun nantinya.
} 
tergerusnya Bali dari masyarakatnya sendiri menjadi hal yang niscaya. Sementara itu, gagasan Ajeg Bali yang secara dominan berusaha menjawab tantangan ini masih jauh dari memuaskan dalam menyediakan kerangka solutif.

Dimensi gagasan dan praktik dari Ajeg Bali cenderung berorientasi ke dalam, dalam arti meneguhkan identitas, akan tetapi tidak mampu menghadapi tantangan kapital yang terus masuk dan mengubah wilayah-wilayah Bali secara dominan. Dalam waktu yang tidak jauh, aliranaliran kapital ini akan semakin gencar memasuki Bali. Pecalang yang notabene diharapkan menjadi penjaga adat atas nama tradisi pun tidak dapat menghindar dari kuasa kapital ini. Dalam hemat penulis, ke depannya masih diperlukan perdebatan mendalam tentang Ajeg Bali yang terbuka dan sirkuler dalam masyarakat. Kelompok Media Bali Post yang selama ini menjadi corong harus didorong peranannya dalam menyediakan seluruh informasi terkait dengan kondisi Bali terkini sehingga semakin membuka ruang-ruang sosial yang aktif bagi masyarakat penikmat media di Bali.

Ke depannya, masih perlu dikaji lagi, bagaimana tanggapan dan respon menyeluruh masyarakat Bali tentang problematika yang hadir dihadapannya. Prospek perubahan masih besar, di mana tradisi masyarakat Bali tidak dapat dipandang sebagai sesuatu yang statis dan lampau. Perlu ada proses pembelajaran dari pengalaman masa lalu, sejarah, sehingga dapat mengambil hikmah dan menjadi modal yang kuat ditengah-tengah derasnya arus global. Pemahaman akan kondisi saat ini menjadi titik acuan dalam mengambil sikap guna menghadapi tantangan-tantangan di masa depan.
Masa depan Bali berada di tangan pemudapemudanya yang menjadi subjek utama dari dinamika perubahan yang berlangsung hingga kini. ${ }^{12}$ Sikap kaum muda inilah menentukan bagaimana nasib Bali nantinya. Sudah saatnya kita sadar, mau belajar, dan terbuka, tetapi juga kritis dalam memahami realitas. Jangan sampai kita terlena dengan janji-janji material kapital, dan meninggalkan pengetahuan lokal yang terus dipertahankan hingga saat ini. Melalui kontekstualisasi dari pengetahuan lokal inilah terletak gudang gagasan dalam menghadapi perubahan di Bali.

\section{Daftar Acuan}

Anderson, Benedict. (1972). Revolusi Pemoeda:

Pendudukan Jepang dan Perlawanan di Jawa

1944-1946. (Judul asli, Java in a Time of

Revolution: Occupation and Resistance 1994-

1946, Ithaca, New York:Cornel University

Press, 1972).

Allen, Pamella \& Palerma, Carmencita. (2005). Ajeg

Bali: Multiple Meaning, Diverse Agenda.

Indonesia and the Malay World, 33:97, 239-

25

Michel Foucault. (2002). Power/Knowledge, Wacana

Kuasa/Pengetahuan. Yogyakarta:Bentang , 2002.

Laclau, Ernesto dan Chantal Mouffe. (2008).

Hegemoni dan Strategi Sosialis: Pos Marxisme

\footnotetext{
${ }^{12}$ Konsep Pemuda disini secara longgar menerapkan kategori yang ditawarkan Benedict R'OG. Anderson. Lebih jauh periksa Benedict R'OG. Anderson, Revolusi Pemoeda: Pendudukan Jepang dan Perlawanan di Jawa 1944-1946. (Judul asli, Java in a Time of Revolution: Occupation and Resistance 1994-1946, Ithaca, New York: Cornell University Press, 1972).
} 
dan Gerakan Sosial Baru. Yogyakarta:Resist

Book. (Judul asli, Hegemony and Socialist

Strategy: TowardaRadicalDemocratic Politic,

London: Verso, 2001, edisi kedua, naskah asli

terbit 1985).

Laclau, Ernesto. (1990). New Reflection on The

Revolution of Our Time, London:Verso

Suryawan, I Ngurah. (2005). Bali, Narasi dalam

Kuasa:Politik dan Kekerasan di Bali.

Yogyakarta:Penerbit Ombak. 